\title{
Studies on Acrylonitrile Polymerization
}

\section{Inhibition Period of Redox Polymerization}

\section{By Isamu Yamazaki}

The inhibition period of acrylonitrile polymerization initiated mainly by the $\mathrm{K}_{2} \mathrm{~S}_{2} \mathrm{O}_{8}-\mathrm{AgNO}_{3}$ redox recipe was investigated in various conditions. It was extremely shortened by adding a very small quantity of $\mathrm{AgNO}_{3}$, and it was proportional to the inhibitor-concentration and to the reciprocals of both the activator and the initiator-concentrations, but was indistinctly affected by the monomer concentration under various temperatures.

\section{第 4 報 レドックス重合に及ぼすジビニルアセチレンの影響}

(1956 年 2 月 24 日受理)

山

崎

勇

要旨各種のレドックス好方によるアクリロニトリルの重合反応におけるジビニルアセチレン添加 の影響を検討した。いずれの反応系においてもジビニルアセチレンは典型的な禁止剤的举動を示し，禁止期 を長くしアクリロニトリルの消費速度とその重合体の平均重合度を変化する。禁止期間の測定から各レドッ クス采の強さを比較した。

\section{I. 緒 言}

直接合成法によるアクリロニトリルの製造に際して副生するジビニルアセチレンは, 通常の重 合反応を著しく阻害する。これについてはすでにいくつかの報告”もあり，また藷者も第 1 報で 検討した。これと同じ禁止作用が各種レドックス采重合にも見出される。本報告は 3 種のレドッ クス重合におけるジビニルア七チレンの禁止作用を比較した結果である。

材 料：触媒の過硫酸カリ (KPS と略記) とアクリロニトリル (AN) は前報と同一物を用い た。還元剤として使用したものは酸性严硫酸ソーダと硝酸銀および八イドロキノンの 3 種であっ て前 2 者は各 1 級品を, 後者は市販品を再結晶により精製した。

ジビニルアセチレン2ははニューランド触媒によるアセチレンの重合で製造し, 数回分別蒸溜し た沸点 $83.5^{\circ} \mathrm{C}$ の溜出部分である。

測定方法： 䈍止期と単量体消費速度は第 1 報に記載した膨張計によりその容積収縮量から求 めた。また平均重合度はジメチルホルムアミド溶液として粘度法3)により測定したが、いずれも 重合率 10〜20\%ぐらいでメタノールにより沈晸分離した初期重合物を用いた。 


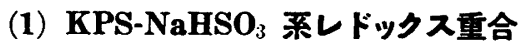

第 1 図はこの系にジビニルアセチレンを添加した場合その量と重合曲線の関係を示したもので ある。その添加量の増加に従い禁止期が長くなり，その終了後はじまる AN の消費速度もまた小 さくなっている。これらの測定値は第 1 表に示したが, その初期重合物の平均重合度はジビニル アセチレン無添加のときのみ小さく，その他は添加量によらない一定值を示している。第 2 図は ジビニルアセチレン添加量と AN の消費速度の関倸図であるが, その添加量の小さい間はほぼ直 線的に速度が低下することが明らかである。禁止期はレドックス重合系でも非レドックス系と同 じくジビニルアセチレン量に比例して長くなる。これは第 3 図である。この図で $40.0^{\circ} \mathrm{C}$ の直線

第 1 表 KPS- $\mathrm{NaHSO}_{3}$ 采レドックス重合に及ぼすジビニルアセチレン添加の影響

処方: 水 $50.0 \mathrm{~g}, \mathrm{AN} 4.0 \mathrm{~g}, \mathrm{KPS} 0.050 \mathrm{~g}$, ジビニルアセチレン各量 $\mathrm{NaHSO}_{3} 3.0 \times 10^{-3} \mathrm{~g}$, 温度： $30.0^{\circ} \mathrm{C}$ ただし $\mathrm{NaHSO}_{3}$, ジビニルアセチレンは各々水, $\mathrm{AN}$ 溶液として使用した。

\begin{tabular}{|c|c|c|c|c|}
\hline 実験番号 & 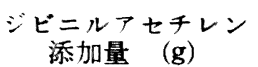 & 禁止期 (分) & $\begin{array}{c}\text { 単量体消費速度 } \\
\mathrm{mol} / l \cdot \mathrm{sec}\end{array}$ & 平均重合度 \\
\hline 1 & 0 & 3 & $4.43 \times 10^{-4}$ & 4,050 \\
\hline 2 & 0.0186 & 34 & $2.46 \quad "$ & 10,300 \\
\hline 3 & 0.0372 & 73 & 1.23 & 12,100 \\
\hline 4 & 0.0558 & 117 & $1.06 \prime \prime$ & 12,600 \\
\hline
\end{tabular}

処方: 同一, 温度 $40.0^{\circ} \mathrm{C}$

\begin{tabular}{l|l|r|r|r}
\hline 5 & 0 & 2 & $6.15 \times 10^{-4}$ & 5,200 \\
6 & 0.0186 & 26 & $4.35 \prime \prime$ & 12,100 \\
7 & 0.0372 & 64 & $1.89 \prime \prime$ & 12,300 \\
8 & 0.0558 & 105 & $1.23 \prime \prime$ & 12,100 \\
\hline
\end{tabular}

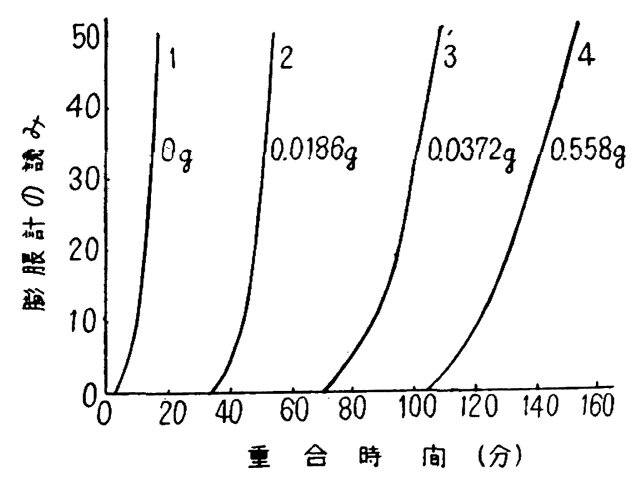

第 1 图 KPS- $\mathrm{NaHSO}_{3}$ 系レドックス重合に及 ぼすジピニルアセチレン添加の影響 $\left(30.0^{\circ} \mathrm{C}\right.$ 添字はジビニルアセチレン添加量)

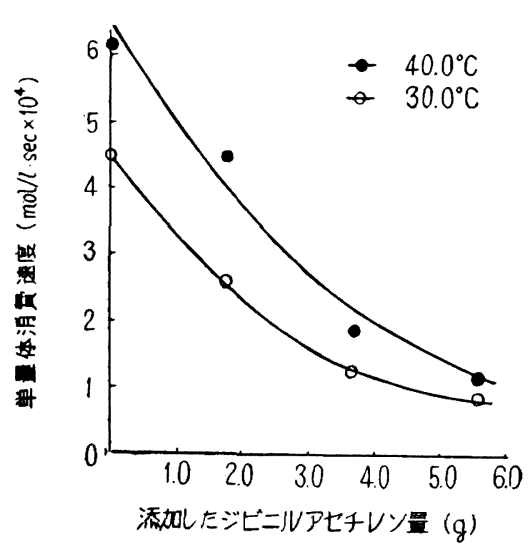

第 2 図 ジビニルアセチレン添加最と管 量体消費速度の関係（KPS- $\mathrm{NaHSO}_{3}$ 系) 
の傾斜が $30.0^{\circ} \mathrm{C}$ のそれよりも小さいことはこの采の開始反 応と関係してすでに第 3 報で検討した。

\section{(2) $\mathrm{KPS}-\mathrm{AgNO}_{3}$ 系レドックス重合}

同系レドックス重合の詳しい検討は後に報告するが，この 系においてもジビニルアセチレンは強力な禁止作用を示す。 第 2 表は (1) と同一条件で行った重合結果であるが,ここでも また前系で見出されたと同一傾向すなわち禁止期はジビニル アセチレン添加量に比例して長くなり，AN の消費速度は漸 减する。

\section{(3) KPS-ハイドロキノン系レドックス重合}

第 3 表は前系と同一条件で測定した結果であって，禁止期

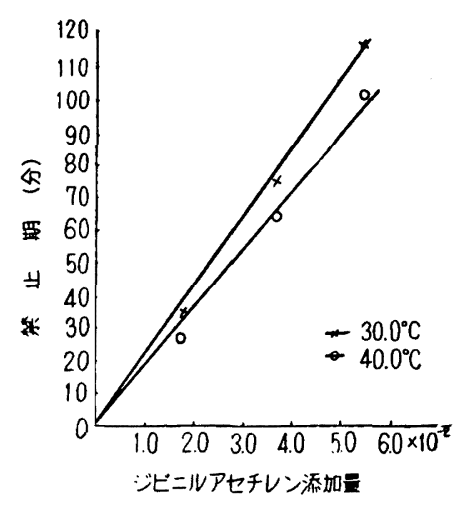

第 3 図レドックス重合の禁止期と ジビニルアセチレン添加量の関係 $\left(\mathrm{KPS}-\mathrm{NaHSO}_{3}\right.$ 系) と単量体消費速度の変化する傾向は全く前二系と同一である。しかし平均重合度は KPS$\mathrm{NaHSO}_{3}$ 系のごとく明腹なジビニルアセチレン添加の影響を示さない。

第 2 表 $\mathrm{KPS}-\mathrm{AgNO}_{3}$ 系レドックス重合に及ぼすジビニルアセチレン添加の影響 処方: 水 $50.0 \mathrm{~g}, \mathrm{KPS} 0.050 \mathrm{~g}, \mathrm{AN} 4.0 \mathrm{~g}, \mathrm{AgNO}_{3} 0.010 \mathrm{~g}$ ジビニルアセチレン各量 㵋度： $40.0^{\circ} \mathrm{C}$

\begin{tabular}{c|c|c|c|c}
\hline \hline 実験番号 & $\begin{array}{c}\text { ジビニルアセチレン } \\
\text { 添加量 (g) }\end{array}$ & 禁止期 (分) & $\begin{array}{c}\text { 単量体消費速度 } \\
(\mathrm{mol} / l \cdot \mathrm{sec})\end{array}$ & 平均重合度 \\
\hline 9 & 0 & 7 & $3.25 \times 10^{-4}$ & - \\
\hline 10 & 0.019 & 60 & $2.34 \prime \prime$ & - \\
11 & 0.037 & 100 & $2.21 "$ & - \\
12 & 0.056 & 125 & $1.95 \prime \prime$ & - \\
\hline
\end{tabular}

第 3 表 KPS-ヒドロキノン系レドックス重合に及ぼすジビニルアセチレン添加の影響 処方：水 $50.0 \mathrm{~g}, \mathrm{AN} 4.0 \mathrm{~g}$, KPS $0.050 \mathrm{~g}$, ヒドロキ/ン $0.010 \mathrm{~g}$, ジビニルアセチレン各量 温度： $40.0^{\circ} \mathrm{C}$

\begin{tabular}{c|c|c|c|c}
\hline 実験番号 & $\begin{array}{c}\text { ジビニルアセチレン } \\
\text { 添加量 }(\mathrm{g})\end{array}$ & 禁止期 (分) & $\begin{array}{c}\text { 単量体消費速度 } \\
(\mathrm{mol} / l \cdot \mathrm{sec})\end{array}$ & 平均重合度 \\
\hline 13 & 0 & 5 & $1.63 \times 10^{-4}$ & 1,600 \\
14 & 0.019 & 40 & $0.973 \prime \prime$ & 1,650 \\
15 & 0.037 & 93 & $0.456 \prime \prime$ & 1,200 \\
\hline
\end{tabular}

一般に禁止剤が無添加の場合には，AN の消費速度は KPS 湛度の平方根に比例して変化する が：ジビニルアセチレンが相当多量に存在する場合も第 4 表および第 4 図に示したようにこの関 倸は維持されている。 
第 4 表 KPS-ヒドロキノン系レドックス重合で KPS 濃度を 変化した場合の影響

処方：水 $50.0 \mathrm{~g}, \mathrm{AN} 4.0 \mathrm{~g}$, KPS 各量, ヒドロキノン $0.010 \mathrm{~g}$, ジビニ 温度： $40.0^{\circ} \mathrm{C}$

\begin{tabular}{c|c|c|c|c}
\hline \hline 実験番号 & $\begin{array}{c}\text { KPS 添加量 } \\
(\mathrm{g})\end{array}$ & $\begin{array}{c}\text { 禁止期 } \\
(\text { 分 })\end{array}$ & $\begin{array}{c}\text { 単量体消費速度 } \\
(\mathrm{mol} / l \cdot \mathrm{sec})\end{array}$ & 平均重合度 \\
\cline { 1 - 3 } 16 & 0.030 & 60 & $0.653 \times 10^{-4}$ & 1,300 \\
17 & 0.050 & 40 & $0.980 \quad "$ & 1,650 \\
18 & 0.100 & 30 & $1.53 \quad "$ & 1,100 \\
\hline
\end{tabular}

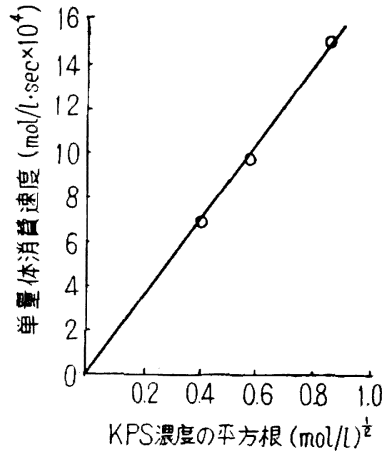

第 4 图 KPS-ヒドロキノン采 レドックス重合に拈けるKPS 濃度の影響 $\left(40.0^{\circ} \mathrm{C}\right)$

\section{考察}

実験によって明らかにしたように，ジビニルアセチレンを添加すると各レドックス系ともその 量に比例して長い禁止期を生じる。これは非レドックス系重合と同じであって，各種レドックス 反応によって生成した KPS からのフリーラジカルが共存するジビニルアセチレンによって脱活 性化反応を受けるためと考えられる。今この禁止作用を各レドックス系について比較するために 次のように行った。第 3 報で詳しく検討したように禁止期は禁止剤濃度に比例し, その比例常数 はその系の開始反応の速度に反比例するから KPS，各還元剤濃度その他の諸条件をすべて一定 にしてジビニルアセチレン添加量を変化すると，その公配から開始反応，したがって各レドック ス系の強さを比べることができる。この測定結果を第 5 表にまとめてある。第 5 図から以上の考 えに基いて, レドックス系の強さは $\mathrm{NaHSO}_{3}>\mathrm{AgNO}_{3}>$ ハイドロキノンの順序であることが わかる。このような関係は第 3 報によると $t=Q / k_{i} c a+B$ の一般式で書き表わされた。第 5 図の

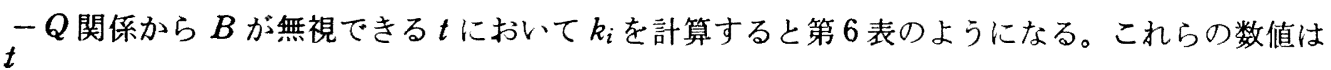
いくつかの仮定の下に計算したものであって大体の大きさを与えているにすぎないが，Baun ${ }^{4)}$ の研究結果によると銀イオンの存在する場合の過硫酸塩の分解速度はその速度式 (1) から計算す

第 5 表 各種レドックス重合の禁止期とジピニルアセチレン添加量の関係

処方：水 $50.0 \mathrm{~g}, \mathrm{AN} 4.0 \mathrm{~g}, \mathrm{KPS} 0.050 \mathrm{~g}$, 還元剂濃度を $0.010 \mathrm{~mol} / l$ とする。ジビニ ルアセチレン各量

温度： $40.0^{\circ} \mathrm{C}$

\begin{tabular}{c|c|c|c}
\hline \hline $\begin{array}{c}\text { ジビニルアセチレン } \\
\text { 添加量 } \\
(\mathrm{g})\end{array}$ & $\begin{array}{c}\mathrm{KPS}-\mathrm{NaHSO}_{3} \\
\text { (分) }\end{array}$ & $\begin{array}{c}\mathrm{KPS}-\mathrm{AgNO}_{3} \\
\text { (分) }\end{array}$ & $\begin{array}{c}\text { KPS-ヒドロキノン系 } \\
\text { (分) }\end{array}$ \\
\hline 0 & 1 & 7 & 8 \\
0.019 & 11 & 63 & 66 \\
0.037 & 28 & 107 & 154 \\
0.056 & 45 & 130 & - \\
\hline
\end{tabular}


第 6 表 各種レドックス系の反応速度恒数 $\left(40.0^{\circ} \mathrm{C}\right)$

\begin{tabular}{|c|c|c|c|c|c|}
\hline \multicolumn{2}{|c|}{ 触 } & \multicolumn{2}{|c|}{ 還 元 剂 } & \multirow{2}{*}{ 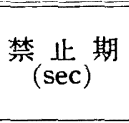 } & \multirow{2}{*}{$\begin{array}{c}\text { 開始反応の速度 } \\
\text { 恒数 }\left(k_{i}\right) \\
k_{i}=Q / t \cdot c \cdot a^{*} \\
\text { mol } / l\end{array}$} \\
\hline 種 類 & 濃度 $(\mathrm{mol} / \mathrm{l})$ & 種 類 & 濃 度 $(\mathrm{mol} / l)$ & & \\
\hline KPS & $3.37 \times 10^{-3}$ & $\mathrm{NaHSO}_{3}$ & $1.16 \times 10^{-2}$ & $38 \times 60$ & 0.151 \\
\hline KPS & " & $\mathrm{AgNO}_{33}$ & " & $117 \times 60$ & 0.0456 \\
\hline KPS & " & ハイドロキノン & $"$ & $187 \times 60$ & 0.0307 \\
\hline
\end{tabular}

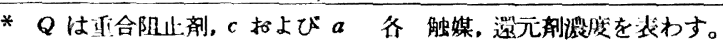

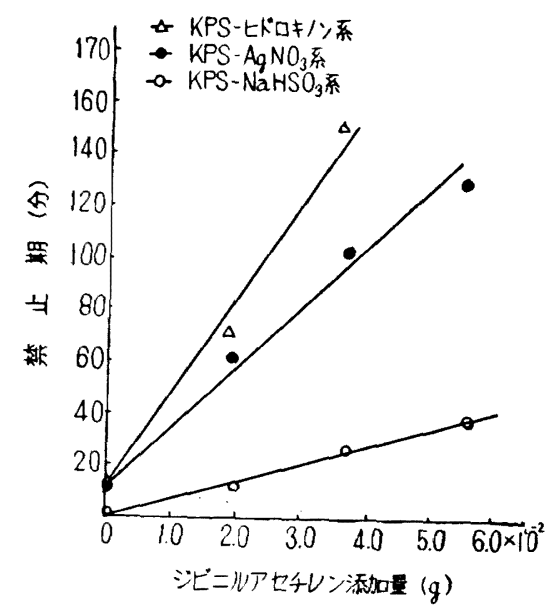

第 5 図同一条件下の各種レドックス重合に おけるジビニルアセチレン添加量と禁止期 の関係 $\left(40.0^{\circ} \mathrm{C}\right)$

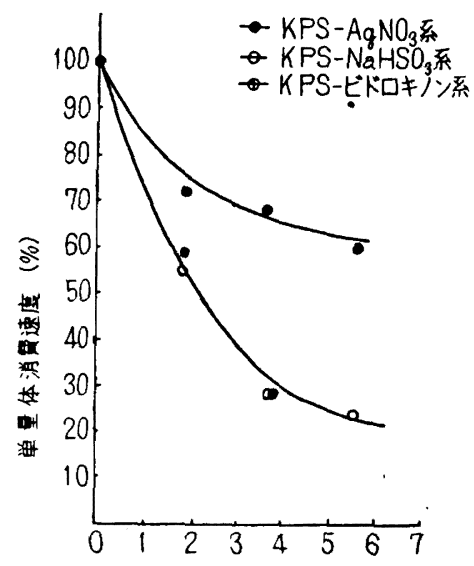

ジビニルアセチレン淩加重 $\left(q \times 10^{2}\right)$

第 6 図 ジビニルアセチレン添加におる 単量体消費速度低下の割合 $\left(40.0^{\circ} \mathrm{C}\right)$

ると $40.0^{\circ} \mathrm{C}$ において

$$
k_{i}=3.1 \times 10^{11} \exp (-17,900 / R T) l^{-1} / \mathrm{mol} \cdot \mathrm{sec}^{-1}
$$

$0.12 \mathrm{~mol} / l \cdot \mathrm{sec}$ となる。第 6 表の数值はこれの約 $1 / 3$ であるが，この相違は測定上の誤差とラジ カルの効率を考虑すると一応妥当な值であろう。

アクリロニトリルの消費速度はジビニルアセチレン添加量の増加とともに漸減するが，第 6 図 で兒るように，特に $\mathrm{KPS}-\mathrm{NaHSO}_{3}$ と KPS-ヒドロキノン系の減少程度が著しい。これら単量 体消費速度低下の原因については次のことが考えられる。

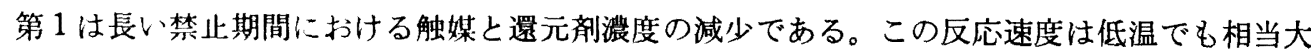
きく禁止剤が共存して比較的長い禁止期を示す場合には，その間の触媒あるいは還元剂の消費量 は無視できない程度になる。たとえば KPS と $\mathrm{NaHSO}_{3}$ の両濃度とも比較的小さくて重合温度 が高く, 禁止凰が多量に存在する系では長い禁止期の終了後急速に重合がはじまり,低収率で重合 が停止することが実験で見出されているが，これは禁止期間中にすでに大部分の触媒と還元剤が 消費されたことによるものと考えられる。他の原因はこの禁止期間に生成した反応生成物が，あ る種の遅延作用によって以後の重合に関係することによるものである。たとえば八イドロキノン 
をレドックス試薬として使用すると, 酸化されて生成したベンゾキノンが遅延剤となり重合の速 度を低下する。

これら 2 つの効果が重なり合って上述の結果をもたらすものであろう。

\section{結論}

ハイドロキノン，硝酸銀と酸性亜硫酸ソーダの3 種の還元剤からつくられたレドックス処方に よるアクリロニトリルの重合反応は，ジビニルアセチレンによって禁止作用を受ける。アクリロ ニトリルの消費速度は前者の添加量とともに小さくなり, 禁止期も比例して長くなる。その関係 から開始反応の大きさが $\mathrm{NaHSO}_{3}>\mathrm{AgNO}_{3}>\mathrm{C}_{6} \mathrm{H}_{4}(\mathrm{OH})_{2}$ の順序であることを明らかにした。

付＼cjkstart記：ジビニルアセチレンの製造は高田幸夫氏の好意によるもので，厚く感謝致します。

\section{文献}

1) W.N. Broatch and C.T. Greenwood: J. Polm. Soc., XIV, 589(1954)

2) 辻雄二訳：“アセチレンの化学” $230(1950)$, 北隆館

3）神原周：“アクリロニトリルの化学” 124, 高分子化学刊行会

4) C.E.H. Baun and D. Margerison: Trans. Faraday Soc., 51, 925 (1955)

\section{Studies on Acrylonitrile Polymerization}

\section{The Effect of Divinyl-acetylene on the Redox Polymerization}

\section{By Isamu Yamazaki}

In the presence of divinyl acetylene, acrylonitrile was polymerized by three typical redox recipes such as $\mathrm{K}_{2} \mathrm{~S}_{2} \mathrm{O}_{8}-\mathrm{AgNO}_{3},-\mathrm{NaHSO}_{3}$, and $-\mathrm{Hydroquinone}$ systems. These redox-polymerizations were inhibited proportinally to the quantity of added divinyl acetylene, and both the monomer consumption rate and the degree of polymerization were reduced considerably. The initiating power of these redox system was compared under the same concentration of each reductant. 